\title{
Optimasi Inventori Dengan Pendekatan Deterministik Dinamis Pada Industri Manufaktur Roti
}

\author{
Yevita Nursyanti ${ }^{1}$, Karina Shalsabila ${ }^{1}$ \\ ${ }^{1}$ Manajemen Logistik Industri Elektronika \\ Politeknik Negeri APP Jakarta, Jl. Timbul No.34, Jakarta Selatan, Daerah Khusus Ibukota Jakarta 12630 \\ email :yevita.nursyanti@gmail.com \\ doi: https://doi.org/10.31315/opsi.v13i2.3517
}

Received: $1^{\text {st }}$ July 2020; Revised: $29^{\text {th }}$ July 2020; Accepted: $7^{\text {th }}$ August 2020;

Available online: $22^{\text {nd }}$ December 2020; Published regularly: December 2020

\begin{abstract}
This research is to optimize the inventory of bakery products by using several approaches to dynamic deterministic methods. Dynamic deterministic methods used in this research are Wagner-Whitin Algorithm, Silver Meal, Least Unit Cost, Economic Part Period, Lot for Lot, Total Cost Least, Period Order Quantity and Part Period Balancing. The best method is the method that produces the lowest total inventory cost. The result of calculating the total inventory cost using the Wagner-Whitin Algorithm method is Rp. 2,006,592 ,. The SilverMeal method generates a total inventory cost of Rp. 2,043,725.49. The Least Unit Cost method generates a total inventory cost of Rp. 1,894,624.18. The Economic Part Period method produces a total inventory cost of Rp. 1,235,546.41. The Lot for Lot method generates a total inventory cost of Rp. 2,835,000.00. The Least Total Cost method generates a total inventory cost of Rp. 1,894,624.18. The Period Order Quantity method generates a total inventory cost of Rp. 2,750,767.97. The Part Period Balancing method generates a total inventory cost of Rp. 1,894,624. From the results of all methods, the best method that can be made a proposal to UD.Roti Isabela is the Economic Part Period method with a policy of ordering 3 times an order with a total inventory cost of Rp 1,235,546.41.
\end{abstract}

Keyword : Optimization, Inventory control, dynamic deterministic

\begin{abstract}
ABSTRAK
Penelitian ini untuk mengoptimalkan persediaan terhadap produk roti dengan menggunakan beberapa pendekatan pada metode deterministik dinamis. Pendekatan deterministik dinamis yang diterapkan pada penelitian ini yaitu Algoritma Wagner-Whitin, Silver Meal, Least Unit Cost, Economic Part Period, Lot For Lot, Least Total Cost, Period Order Quantity dan Part Period Balancing. Metode terbaik adalah metode yang menghasilkan ongkos total inventori terkecil. Hasil perhitungan ongkos total inventori degnan menggunakan metode Algoritma Wagner-Whitin diperoleh ongkos total inventori sebesar Rp. 2.006.592,. Metode SilverMeal menghasilkan ongkos total inventori sebesar Rp. 2.043.725,49. Metode Least Unit Cost menghasilkan ongkos total inventori sebesar Rp. 1.894.624,18. Metode Economic Part Period menghasilkan biaya total inventori sebesar Rp. 1.235.546,41. Metode Lot For Lot menghasilkan total biaya inventori sebesar Rp. 2.835.000,00. Metode Least Total Cost menghasilkan ongkos total biaya inventori sebesar Rp. 1.894.624,18. Metode Period Order Quantity menghasilkan total biaya inventori sebesar Rp. 2.750.767,97. Metode Part Period Balancing menghasilkan ongkos total biaya inventori sebesar Rp. 1.894.624. Dari hasil semua metode, metode terbaik yang dapat dijadikan usulan kepada UD.Roti Isabela adalah metode Economic Part Period dengan kebijakan melakukan pemesanan 3 kali pemesanan dengan total biaya inventorinya sebesar Rp 1.235.546.41.
\end{abstract}

Kata kunci : Optimasi, Pengendalian inventori, deterministik dinamis

\section{PENDAHULUAN}

Persediaan merupakan barang disimpan di gudang untuk kemudiaan dijual atau digunakan dalam proses produksi atau dipakai untuk keperluan non produksi dalam siklus kegiatan yang normal (Tamodia, 2013). Perusahaan harus mampu mengantisipasi keadaan maupun tantangan yang ada dalam manajemen persediaan (Tuerah, 2014) UD. Roti merupakan usaha dagang yang bergerak dalam bidang makanan. Industri ini memproduksi khususnya roti sesuai dengan jumlah permintaan yang diminta oleh agen yang mendistribusikan produk tersebut pada daerah masing-masing. Masalah yang ditemui pada UD. Roti yaitu 
kurang baiknya pengelolaan persediaan material untuk memproduksi atau mengolah menjadi produk jadi. Proses perencanaan pemesanan bahan baku yang akan diproduksi merupakan aktivitas yang dapat mempengaruhi kelancaran proses produksi dan kualitas produk yang akan dihasilkan menurut Apple (1990). Hal ini terjadi karena semua fasilitas yang digunakan masih manual, sehingga memerlukan waktu yang lama untuk proses produksi. Jumlah persediaan yang disimpan di gudang hanya bergantung pada perkiraan. Tujuan dari pengendalian persediaan bahan baku adalah untuk menekan biaya-biaya operasional seminimal mungkin (Lahu \& Sumarauw, 2017).

Berikut adalah grafik perbandingan jumlah pemakaian bahan baku (terigu dan selay stroberi) dengan jumlah persediaan di gudang

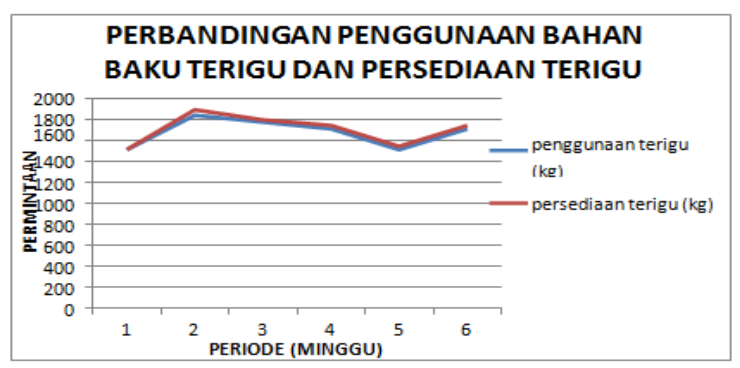

Gambar 1. Grafik perbandingan terigu

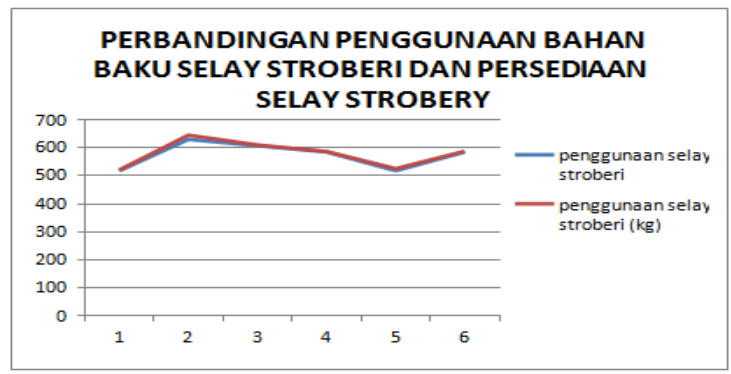

Gambar 2. Grafik perbandingan selay strawberry

Terlihat dari grafik di atas persediaan bahan baku terigu dan selay stroberi mengalami overstock dimana jumlah selay stroberi yang disimpan lebih banyak daripada yang digunakan, sehingga di gudang terdapat penumpukan bahan baku. Penumpukan bahan baku (overstock) menyebabkan tingginya biaya simpan inventori yang berdampak juga terhadap tingginya biaya inventori. Untuk mengurangi jumlah overstock tersebut sehingg perlu dilakukan optimasi jumlah persediaan barang di gudang (Fatma \& Pulungan, 2018). Salah satu caranya adalah dengan melakukan optimasi persediaan melalui pendekatan determininistik dinamis.

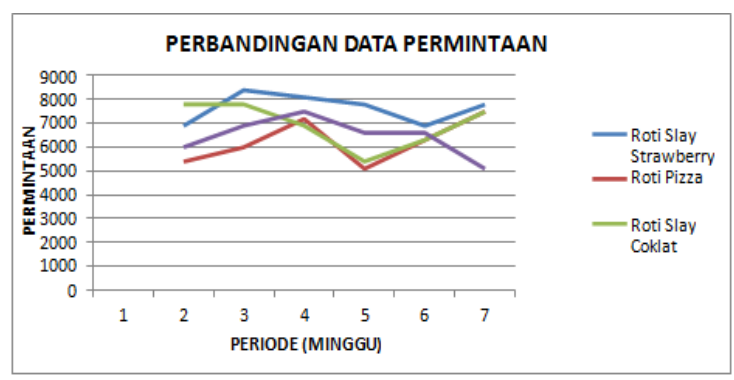

Gambar 3. Grafik perbandingan data permintaan

Berdasarkan gambaran grafik di atas perlunya untuk melakukan pengendalian persediaan yang optimal untuk produk Roti pada UD. Roti, sehingga bisa menyelesaikan permasalahan overstock yang selama ini terjadi pada UD. Roti. Terdapat beberapa jenis fenomena persediaan yaitu persediaan yang bersifat statis dan persediaan yang bersifat dinamis menurut Bahagia (2006)

\section{METODE PENELITIAN}

Menurut Handoko (1995) sistem persediaan adalah serangkaian kebijakan dan pengendalian yang memonitor tingkat persediaan dan menentukan tingkat persediaan yang harus dijaga, kapan persediaan harus diisi, dan berapa besar pesanan yang harus dilakukan. Selain itu menurut Heizer dan Render (2011) sistem kebijakan persediaan dapat didefinisikan sebagai serangkaian kebijakan pengendalian pesediaan untuk menentukan tingkat persediaan harus dilakukan dan berapa pesanan harus diadakan.

Pada tahap awal mengindentifikasi proses persediaan bahan baku pada UD. Roti. Industri menerapkan proses penerimaan pesanan terlebih dahulu, metode ini digunakan oleh perusahaan yang memproduksi barang berdasarkan pesanan atau sesuai dengan keinginan konsumen (Nangin, Nangoi, \& Tirayoh, 2018). Hal ini mengharuskan UD. Roti memiliki persediaan yang cukup untuk memenuhi kebutuhan konsumennya dengan permintaan yang pasti dan berbeda beda.

Pada tahap pengolahan data akan menggunakan beberapa jenis metode deteriministik dinamis. Optimalitas persediaan akan ditentukan berdasarkan metode terbaik yang memberikan jumlah biaya inventori paling rendah serta jumlah pemesanan yang 
ekonomis (Limbong, Tarore, Tjakra, \& Walangitan, 2013). Data yang diperoleh dari hasil observasi lapangan akan dioah berdasarkan tahapan berikut ini:

1. Pengumpulan data pada saat observasi lapangan berupa data permintaan untuk periode Januari 2020 - Februari 2020. Datadata ini diperoleh langsung dari pemilik UD. Roti baik melalui wawancara maupun dokumen.

2. Berdasarkan hasil pengumpulan data di atas maka dilakukan proses perhitungan biaya simpan serta biaya pesan yang dikeluarkan oleh perusahaan.

3. Menentukan inventori optimal melalui perhitungan ukuran lot pemesanan (q) yang ekonomis agar tidak terjadi overstock di gudang.

Untuk melakukan pengendalian persediaan yang optimal maka bisa menggunakan beberapa pendekatan deterministik dinamis (Hadiyanti \& Siregar, 2018) yaitu :

a. Lot for Lot (LFL)

Pendekatan ini memiliki kelebihan yaitu tidak terdapat ongkos simpan. Hal ini disebabkan oleh barang langsung diproses produksi sehingga tidak adanya barang yang disimpan di dalam gudang.

b. $\quad$ Least Unit Cost (LUC)

Iterasi pada metode ini berdasarkan ongkos total perunit, semakin turun nilai ongkos total perunit maka bisa dilakukan penambahan cakupan lot pemesanan.

c. Least Total Cost (LTC)

Acuan iterasi pada metode ini adalah cakupan lot ukuran pemesanan akan ditambah jika besar ongkos simpan kumulatifnya belum melebihi besar ongkos pesannya.

d. Economic Part Period (EPP)

Metode EPP ini sekilas memiliki langkah penyelesaian yang mirip dengan LTC hanya saja pada metode ini yang menjadi dasar perhitungan biya simpan kumulatif dan jumlah barang period kumulatifnya.

e. Part Period Balancing (PPB)

Metode ini diawali dengan iterasi penambahan ukuran atau cakupan lot dilakukan jika prosedur look ahead berhasil, namun jika prosedur look ahead gagal maka dilakukan pengurangan cakupan lot seperti semula atau disebut juga dengan prosedur look back, jika hasil look back juga gagal maka hasil kebijakan dengan EPP adalah yang optimal.

f. Period Order Quantity (POQ)

Metode ini menggunakan prinsip deterministik statis dengan besar lot pemesanan ekonomisnya tetap dan leadtime yang sama panjang setiap kali pemesanannya.

g. Silver Meal

Pendekatan ini berdasarkan ongkos satuan inventori per periode, jika ongkos satuan per periode mengalami penurunan maka dilakukan penambahan cakupan lot pemesanan namun jika dihasilkan sebaliknya maka penambahan dihentikan dan diulang kembali untuk periode berikutnya.

h. Wagner Within

Pendekatan ini merupakan pengembangan algoritma untuk menyelesaikan permasalahn inventori deterministik dinamis dengan menggunakan sistem matriks.

\section{HASIL DAN PEMBAHASAN}

Berikut adalah beberapa tahapan yang harus dilakukan dalam pengendalian inventori dengan pendekatan deterministik dinamis:

1. Menggunakan data histori (data masa lampau) permintaan pemesanan selama per satu periode perencanaan.

Untuk mencari persediaan optimum pada UD. Roti menggunakan data historis selama satu periode atau 6 minggu di awal bulan januari hingga februari. Data permintaannya dapat dilihat pada Tabel 1 berikut:

Tabel 1. Data Permintaan (ratusan)

\begin{tabular}{lcccccc}
\hline T(Week) & 1 & 2 & 3 & 4 & 5 & 6 \\
\hline Demand & 69 & 84 & 81 & 78 & 69 & 78 \\
\hline
\end{tabular}

2. Menghitung biaya simpan serta biaya pesan yang ada dalam perusahaan.

Pada UD.Roti terdapat biaya simpan dan biaya pesan yang sudah dikeluarkan selama periode perencanaan. Berikut adalah rincian biaya pesan pada UD.Roti (Tabel 2):

Biaya depresiasi kendaraan timbul karena perusahaan memiliki kendaraan yang berfungsi untuk membeli bahan baku jika terjadi hambatan pada supplier dalam hal pengiriman sehingga UD.Roti yang akan mengambil langsung ke supplier. Kemudian biaya bahan bakar timbul akibat pemakaian kendaraan yang 
ada. Biaya internet dikeluarkan oleh perusahaan karen internet diperlukan dalam hal melakukan pemesanan bahan baku ke supplier. Selain biaya pesan terdapat pula biaya simpan yang dikeluarkan oleh UD.Roti seperti Tabel 3.

Biaya simpan yang terdiri dari biaya sewa bangunan dan listrik timbul karena terdapatnya sejumlah barang yang harus disimpan di dalam gudang selama periode waktu penyimpanan tertentu.

Tabel 2. Biaya Pesan

\begin{tabular}{llrrr}
\hline Keterangan & F & $\begin{array}{c}\text { Harga/ } \\
\text { Minggu }\end{array}$ & Total biaya \\
\hline Depresiasi & 1 & Rp 437,500 & Rp 437,500 \\
Kendaraan & & Rp 10,000 & Rp 10,000 \\
Bahan bakar & 1 & Rp 25,000 & Rp 25,000 \\
Internet & 1 & Rp & Rp 472,500. \\
\hline \multicolumn{2}{c}{ Total Biaya Pesan }
\end{tabular}

Tabel 3. Biaya simpan

\begin{tabular}{lccc}
\hline Keterangan & F & Harga & Total biaya \\
\hline $\begin{array}{l}\text { Sewa } \\
\text { bangunan }\end{array}$ & 1 & Rp 52,083 & Rp 52,083 \\
Listrik & 1 & Rp 100,000 & Rp 100,000 \\
\hline \multicolumn{2}{c}{ Total Biaya Simpan/minggu } & Rp 152,083 \\
\hline \multicolumn{2}{r}{ Total Biaya Simpan/Unit } & Rp 19.88 \\
\hline
\end{tabular}

3. Menghitung ukuran lot pemesanan ekonomis dan frekuensi pemesanan dengan menggunakan beberapa metode deteriministik dinamis.

\subsection{Metode Lot For Lot (LFL)}

Perhitungan metode Lot For Lot apabila pemesanan dilakukan pada periode pertama dengan lead time 1 periode maka barang yang dipesan dikirim pada periode 0 atau pada periode sebelumnya. Berikut tabel kebijakan dan tabel total ongkos inventori metode Lot For Lot (Tabel 4):

Tabel 4. Kebijakan inventory metode LFL (ratusan)

\begin{tabular}{cccccccc}
\hline $\mathrm{T}$ & 0 & 1 & 2 & 3 & 4 & 5 & 6 \\
\hline $\mathrm{D}$ & & 69 & 84 & 81 & 78 & 69 & 78 \\
Lot & & 69 & 84 & 81 & 78 & 69 & 78 \\
POR & 69 & 84 & 81 & 78 & 69 & 78 & \\
\hline
\end{tabular}

Setelah dilakukan perhitungan, maka didapatkan hasil ongkos total inventori sebesar $\mathrm{Rp}$ 2.835.000, untuk lebih jelasnya digambarkan pada Tabel 5 berikut :
Tabel 5. Ongkos total LFL

\begin{tabular}{ll}
\hline & LFL \\
\hline Ongkos Pesan & $\mathrm{Rp} 2.835 .000,00$ \\
Ongkos Simpan & $\mathrm{Rp}$ \\
Ongkos Total & $\mathrm{Rp} 2.835 .000,00$ \\
\hline
\end{tabular}

Metode LFL ini bertujuan untuk meminimumkan biaya simpan, terutama bagi perusahaan yang memiliki item-item barang dengan biaya simpan yang sangat mahal. Kelemahan yang ada pada metode ini adalah akan membebankan semua biaya pada biaya pesan dengan enam kali frekuensi pemesanan.

Kelebihan dalam menggunakan metode ini adalah dalam tidak terdapat biaya simpan sehingga metode ini cocok apabila perusahaan memiliki penyimpanan dengan nilai barang yang mahal, sedangkan untuk kelemahannya adalah biaya pemesanannya tinggi dengan frekuensi pemesanan yang tinggi juga. Apabila ada kesalahan yang terjadi secara tiba-tiba seperti jumlah pemesanan yang jumlahnya lebih besar dari jumlah persediaan, maka akan menyebabkan out of stock sehingga perusahaan tidak akan memenuhi permintaan yang menyebabkan service level akan menurun.

\subsection{Metode Least Unit Cost (LUC)}

Perhitungan dengan menggunakan metode LUC untuk menentukan lot pemesanan ekonomis berdasarkan pada satuan ongkos total per unit yang dihasilkan pada setiap periode penyimpanan. Tabel 6 merupakan perhitungan untuk metode LUC:

Pada tabel tersebut, ongkos satuan per unit minimum dicapai bila ukuran lot mengalami penurunan dari minggu sebelumnya. Tabel 7 merupakan kebijakan inventory metode LUC:

Berdasarkan Tabel kebijakan inventori di atas maka diperoleh hasil bahwa pemesanan dilakukan sebanyak 3 kali pemesanan dengan hasil ongkos total inventori dapat dilihat pada Tabel 8.

Berdasarkan hasil perhitungan metode LUC ini memiliki kelebihan bahwa biaya simpan nya lebih rendah dibandingkan biaya pesan hal ini dikarenakan hanya ada tiga periode simpan di gudang.

\subsection{Metode Least Total Cost (LTC)}

Dasar pendekatan pengukuran lot ekonomis dengan menggunakan metode LTC adalah menyeimbangkan antara ongkos simpan dan ongkos pesan dimana ongkos inventory 
Tabel 6. Perhitungan metode LUC

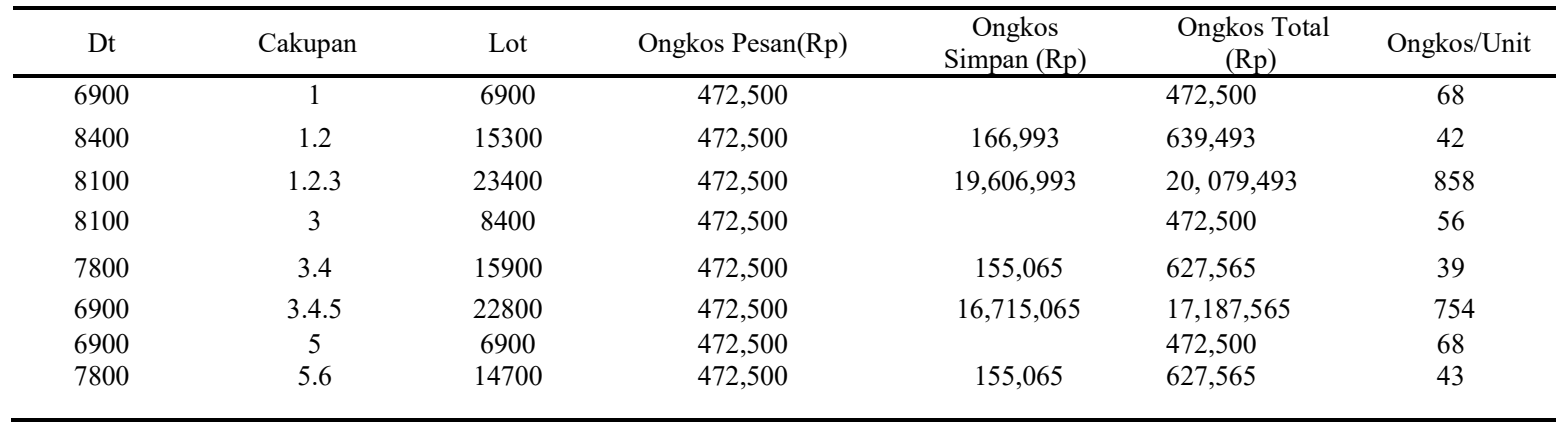

Tabel 7. Kebijakan inventori metode LUC (ratusan)

\begin{tabular}{cccccccc}
\hline \multicolumn{7}{c}{ TABEL KEBIJAKAN METODE LUC } \\
\hline $\mathrm{T}$ & 0 & 1 & 2 & 3 & 4 & 5 & \\
$\mathrm{D}$ & & 69 & 84 & 81 & 78 & 69 & 78 \\
Lot & & 153 & & 159 & & 147 & \\
Por & 153 & & 159 & & 147 & & \\
\hline
\end{tabular}

Tabel 8. Ongkos total metode LUC

\begin{tabular}{ll}
\hline & LUC \\
\hline Ongkos Pesan & Rp 1.417.500,00 \\
Ongkos Simpan & Rp 477.124,18 \\
Ongkos Total & Rp1.894.624,18 \\
\hline
\end{tabular}

Tabel 9. Perhitungan metode LTC

\begin{tabular}{ccccc}
\hline Dt & Lot & $\begin{array}{c}\text { Periode } \\
\text { simpan }\end{array}$ & $\begin{array}{c}\text { Ongkos } \\
\text { simpan(Rp) }\end{array}$ & $\begin{array}{c}\text { Ongkos simpan } \\
\text { kumulatif(Rp) }\end{array}$ \\
\hline 6900 & 6900 & 0 & - & - \\
8400 & 15300 & 1 & $166.993,46$ & 166.993 \\
8100 & 23400 & 2 & $322.058,82$ & 489.052 \\
8100 & 8100 & 0 & - & - \\
7800 & 15900 & 1 & $155.065,36$ & 155.065 \\
6900 & 22800 & 2 & $274.346,41$ & 548.692 \\
6900 & 6900 & 0 & $137.173,20$ & - \\
7800 & 14700 & 1 & $155.065,36$ & 155.065 \\
\hline
\end{tabular}

total minimum akan dicapai pada saat ongkos simpan dan ongkos pesan berimbang atau sama. Hasil perhitungan ukuran lot ekonomis bisa dilihat pada Tabel 9.

Dari hasil perhitungan lot pemesanan ekonomis di atas maka diperoleh kebijkan inventori dengan menggunakan metode LTC, seperti pada Tabel 10 .

Tabel 10. Kebijakan inventory metode LTC (ratusan)

\begin{tabular}{cccccccl}
\hline \multicolumn{1}{c}{ TABEL KEBIJAKAN METODE LTC } \\
\hline $\mathrm{T}$ & 0 & 1 & 2 & 3 & 4 & 5 & 6 \\
$\mathrm{D}$ & & 69 & 84 & 81 & 78 & 69 & 78 \\
Lot & & 153 & & 159 & & 147 & \\
Por & 153 & & 159 & & 147 & & \\
\hline
\end{tabular}

Berdasarkan hasil perhitungan maka bisa dilihat bahwa hasil pendekatan LTC sama dengan metode LUC dimana pemesanan dilakukan sebanyak 3 kali. Pada Tabel 11 dapat dilihat hasil perhitungan ongkos total inventori.

Tabel 11. Ongkos total metode LTC

\begin{tabular}{ll}
\hline & LTC \\
\hline Ongkos Pesan & Rp 1.417.500 \\
Ongkos Simpan & Rp 477.124,18 \\
Ongkos Total & Rp1.894.624,18 \\
\hline
\end{tabular}

Sama halnya dengan pendekatan LUC hasil perhitungan metode LTC ini memiliki kelebihan bahwa biaya simpannya lebih rendah 
dibandingkan biaya pesan hal ini dikarenakan hanya ada tiga periode simpan di gudang.

\subsection{Metode Period Order Quantity (POQ)}

Pendekatan POQ ini menggunakan prinsip deterministik statis dengan besar lot pemesanan ekonomisnya tetap dan leadtime yang sama panjang setiap kali pemesanannya. Sehigga untuk tahap awal dihitung terlebih dahlu nilai Q dengan menggunakan metode statis Wilson (Tabel 12).

Tabel 12. Perhitungan Metode POQ

\begin{tabular}{lcc}
\hline EOQ & 46710,2 & 46711 \\
\hline Frekuensi & 0,98264 & 1 \\
Periode Cakupan & 6 & 6 \\
\hline
\end{tabular}

Setelah dilakukan perhitungan, dilanjutkan dengan menentukan kebijakan invnetori yang bisa dilihat pada Tabel 13 .

Tabel 13. Kebijakan inventory metode POQ (ratusan)

\begin{tabular}{llcccccc}
\hline \multicolumn{7}{c}{ TABEL KEBIJAKAN METODE OPQ } \\
\hline $\mathrm{T}$ & 0 & 1 & 2 & 3 & 4 & 5 & 6 \\
$\mathrm{D}$ & & 69 & 84 & 81 & 78 & 69 & 78 \\
Lot & & 459 & & & & & \\
Por & 459 & & & & & & \\
\hline
\end{tabular}

Berikut ini adalah ongkos total inventori dengan menggunakan metode POQ seperti pada Tabel 14.

Tabel 14. Ongkos total metode POQ

\begin{tabular}{ll}
\hline & POQ \\
\hline Ongkos Pesan & Rp 472.500 \\
Ongkos Simpan & Rp 2.278.267,97 \\
Ongkos Total & Rp 2.750.767,97 \\
\hline
\end{tabular}

Berdasarkan Tabel 14 UD. Roti hanya perlu melakukan pemesanan bahan baku satu kali saja kepada supplier. Hal ini dikarenakan metode POQ ini memiliki 6 cakupan periode, yang berarti hanya dengan satu kali pemesanan saja, UD.Roti dapat memenuhi kebutuhannya selama enam periode. Hal ini dapat menurunkan biaya pemesanan yang timbul. Selain dari segi biaya, ada rasa tenang yang timbul dari pelaku industri, karena mereka dapat memiliki persediaan untuk beberapa periode kedepan. Hal ini sangat berguna, karena pelaku usaha dapat berfokus dengan aktivitas yang lain tanpa harus terlalu memikirkan mengenai persediaannya.

Metode POQ ini cocok diterapkan jika supplier yang dimiliki oleh UD. Roti memiliki jarak yang cukup jauh dari tempat usaha UD. Roti dan menyebabkan lamanya lead time yang dibutuhkan untuk mengirim barang kepada UD. Roti. Namun disisi lain, untuk menerapkan metode POQ ini pada kegiatan usaha UD. Roti membutuhkan tempat penyimpanan atau gudang yang cukup luas.

Hal ini dikarenakan sekali barang datang supplier data perusahaan, pasti dengan jumlah yang cukup besar karena untuk memenuhi kebutuhan produksi untuk beberapa periode kedepannya. Jika UD. Roti memiliki persediaan yang banyak di gudang, otomatis akan membuat ongkos simpan yang harus dikeluarkan oleh UD. Roti jauh lebih besar. Biaya-biaya yang akan timbul seperti biaya material handling, biaya listrik dan penunjang lainnya, biaya pajak persediaan, biaya kerusakan persediaan, biaya kehilangan persediaan, biaya asuransi persediaan, dan yang pasti adalah biaya modal yang harus dikeluarkan untuk membeli barang tersebut.

\subsection{Metode Silver Meal}

Pada perhitungan metode silver-meal ini (Tabel 15), menggunakan suatu ongkos inventori per periode yang terkecil sebagai ukuran kriteria kinerjanya.

Tabel 15. Perhitungan metode silver meal

\begin{tabular}{|c|c|c|c|c|c|c|c|}
\hline $\mathrm{T}$ & $\mathrm{Dt}$ & $\mathrm{T}$ & Lot & Ongkos Pesan & Ongkos Simpan & $\begin{array}{c}\text { Ongkos } \\
\text { Total }\end{array}$ & Ongkos/periode \\
\hline 1 & 6900 & 1 & 6900 & Rp 472.500 & 0 & $\operatorname{Rp} 472.500$ & $\operatorname{Rp} 472.500$ \\
\hline 2 & 8400 & 2 & 15300 & Rp 472.500 & Rp 166.993,46 & Rp 639.493 & Rp $319.746,73$ \\
\hline 3 & 8100 & 3 & 23400 & Rp 472.500 & Rp 489.052 & Rp 961.552 & Rp 320.517 \\
\hline 4 & 7800 & 4 & 31200 & Rp 472.500 & Rp 954.248,37 & $\begin{array}{c}\mathrm{Rp} \\
1.426 .748\end{array}$ & Rp 356.687 \\
\hline 4 & 7800 & 1 & 7800 & Rp 472.500 & 0 & $\mathrm{Rp} 472.500$ & $\mathrm{Rp} 472.500$ \\
\hline 5 & 6900 & 2 & 14700 & Rp 472.500 & Rp 137.173,20 & Rp 609.673 & Rp 304.837 \\
\hline 6 & 7800 & 3 & 22500 & Rp 472.500 & Rp 447.303,92 & Rp 919.804 & Rp 306.601 \\
\hline 6 & 7800 & 1 & 7800 & Rp 472.500 & 0 & $\mathrm{Rp} 472.500$ & $\mathrm{Rp} 472.500$ \\
\hline
\end{tabular}


Tabel 16. Kebijakan inventory metode silver meal (ratusan)

\begin{tabular}{lccccccc}
\hline \multicolumn{1}{c}{ TABEL KEBIJAKAN } & METODE SILVER-MEAL \\
\hline T & 0 & 1 & 2 & 3 & 4 & 5 & 6 \\
(Minggu) & & & & & & & \\
Demand & 69 & 84 & 81 & 78 & 69 & 78 \\
Lot & & 234 & & & 147 & & 78 \\
POR & 234 & & & 147 & & 78 & \\
\hline
\end{tabular}

Tabel 17. Ongkos total silver meal

\begin{tabular}{ll}
\hline \multicolumn{2}{c}{ Silver-Meal } \\
\hline Ongkos Pesan & Rp 1.417.500,00 \\
Ongkos Simpan & Rp 626.225,49 \\
Ongkos Total & Rp 2.043.725,49 \\
\hline
\end{tabular}

Tabel 18. Perhitungan metode EPP

\begin{tabular}{|c|c|c|c|c|c|}
\hline \multicolumn{3}{|c|}{ EPP } & \multicolumn{3}{|c|}{23767} \\
\hline $\mathrm{T}$ (Minggu) & Dt & Lot & $\begin{array}{l}\text { Periode } \\
\text { Simpan }\end{array}$ & Unit Periode & $\begin{array}{l}\text { Unit Periode } \\
\text { Kumulatif }\end{array}$ \\
\hline 1 & 6900 & 6900 & 0 & 0 & 0 \\
\hline 2 & 8400 & 15300 & 1 & 8400 & 8400 \\
\hline 3 & 8100 & 23400 & 2 & 16200 & 24600 \\
\hline 3 & 8100 & 8100 & 0 & 0 & 0 \\
\hline 4 & 7800 & 15900 & 1 & 7800 & 7800 \\
\hline 5 & 6900 & 22800 & 2 & 13800 & 21600 \\
\hline 6 & 7800 & 30600 & 3 & 23400 & 45000 \\
\hline 6 & 7800 & 7800 & 0 & 0 & 0 \\
\hline
\end{tabular}

Apabila ongkos per unit lebih kecil dari ogkos per unit sebelumnya maka dilakukan penambahan cakupan. Dan begitupun sebaliknya apabila ongkos per unit lebih besar dari pada ongkos per unit maka dilakukan pemberhentian penambahan cakupan dan melakukan pemesanan ulang untuk periode tersebut.

Berdasarkan tabel perhitungan dengan menggunakan metode Silver Meal kemudian akan dilakukan kebijakan inventory untuk melihat ukuran lot sizing 6 periode Tabel kebijakan inventory dapat dilihat pada Tabel 16 , sementara itu ongkos total dari perhitungan ini dapat dilihat pada Tabel 17.

UD.Roti Isabela tidak memerlukan pemesanan setiap minggu dan hanya melakukan pemesanan 3 kali. Sehingga ongkos pesan yang dikeluarkan tidak terlalu tinggi dan juga dengan dilakukannya pemesanan 3 kali ini membuat UD.Roti Isabela tidak memerlukan gudang yang luas sebagai tempat penyimpanan barang tersebut karena produk dipesan dan segera diproduksi dan dijual. Dan dengan adanya frekuensi pemesanan sebanyak 3 kali, maka biaya yang dikeluarkan UD.Roti Isabela untuk melakukan proses penyimpanan barang tidak terlalu tinggi dan cenderung lebih efisien untuk menghasilkan profit yang tinggi dengan menjual produk tersebut kepada konsumen.

Kelebihan metode silver meal yaitu terdapat optimasi dan informasi dari inventory dan satuan ongkos inventori per periode. Kekurangannya salah satunya adalah metode ini hanya menghasilkan nilai optimum lokal namun hasilnya dalam beberapa kasus mendekati metode wagner-within.

\subsection{Metode Economic Part Period (EPP)}

Metode EPP ini, digunakan untuk menentukan ukuran lot pemesanan yang ekonomis berdasarkan unit periode kumulatif nya. Jika unit periode kumulatif mendekati barang periode ekonomis nya maka cakupan lot bisa ditambah. Hasil perhitungannya bisa dilihat pada Tabel 18.

Dari gambaran perhitungan Tabel 18 maka bisa dilihat bahwa terdapat 3 kali pemesanan, untuk lebih jelasnya bisa dilihat pada tabel kebijakan inventori. Kebijakan inventori dari hasil perhitungan EPP dapat dilihat pada Tabel 19. 
Tabel 19. Tabel kebijakan metode EPP(ratusan)

\begin{tabular}{lrrrrrrr}
\hline \multicolumn{7}{c}{ EPP } \\
\hline T & 0 & 1 & 2 & 3 & 4 & 5 & 6 \\
$\mathrm{D}$ & & 69 & 84 & 81 & 78 & 69 & 78 \\
Lot & & 153 & & 228 & & & 78 \\
Por & 153 & & 228 & & & 78 & \\
\hline
\end{tabular}

Setelah diperoleh tabel kebijakan inventori, maka selanjutnya dilakukan perhitungan total ongkos inventori ysng dapat dilihat pada Tabel 20.

Tabel 20. Ongkos total metode EPP

\begin{tabular}{lc}
\hline & EPP \\
\hline Ongkos Pesan & Rp 945.000,00 \\
Ongkos Simpan & Rp 290.546,41 \\
Ongkos Total & Rp 1.235.546,41 \\
\hline
\end{tabular}

Pada tabel perhitungan ongkos total inventori diperoleh bahwa ongkos simpan yang dikeluarkan oleh UD.Roti lebih tinggi dibandingkan ongkos pesan sehingga perusahaan tidak perlu melakukan pemesanan setiap minggu dan hanya melakukan pemesanan 3 kali. Karena ongkos pesan yang tidak terlalu tinggi sehingga tidak memerlukan gudang yang luas sebagai tempat penyimpanan barang tersebut karena produk dipesan dan segera diproduksi.

Kelebihan menggunakan metode lot sizing EPP yaitu metode ini dapat meminimalkan ongkos pesan melalui pertimbangan unit periode kumulatifnya sedangkan kekurangan dari metode ini yaitu dengan menggunakan metode ini,masih terdapat ongkos simpan, dibandingkan dengan metode yang lain yang bisa menghilangkan ongkos simpan.

\subsection{Metode Part Period Balancing (PPB)}

Metode Part Period Balancing ini memiliki dua jenis mekanisme yaitu mekanisme penambahan cakupan lot (look ahead) dan mekanisme pengurangan cakupan lot (look back). Perhitungan metode ini dapat dilihat pada Tabel 21.

Dari hasil perhitungan pada Tabel 21 maka diperoleh hasil tabel kebijakan inventory baru (Tabel 22)

Setelah dilakukan uji part period balancing, periode pemesanan dilakukan 3 kali namun cakupannya berbeda dengan metode Economic Part Period, dimana lot pertama untuk periode 1 dan 2, kemudian lot kedua untuk periode 3 dan 4, dan lot ketiga untuk periode 5 dan periode 6 .

Tabel 21. Perhitungan metode PPB

\begin{tabular}{|c|c|c|c|c|}
\hline \multicolumn{5}{|c|}{ Metode PBB } \\
\hline \multirow{5}{*}{$\begin{array}{c}\text { Look } \\
\text { Ahead (Periode 1- } \\
\text { 2) }\end{array}$} & $\mathrm{N}^{\prime}=$ & 2 & \multirow{5}{*}{$16200>7800$} & \multirow{5}{*}{ Look Ahead Gagal } \\
\hline & $\mathrm{n}=$ & 2 & & \\
\hline & $\mathrm{Dn}+1=$ & 8100 & & \\
\hline & $\mathrm{Dn}+2=$ & 7800 & & \\
\hline & $\mathrm{N}^{\prime} \mathrm{Dn}+1$ & 16200 & & \\
\hline \multirow{7}{*}{$\begin{array}{c}\text { Look } \\
\text { Back (Periode 1-2) }\end{array}$} & $\mathrm{N}^{\prime}=$ & 1 & \multirow{7}{*}{$\begin{array}{l}8400 \\
15900\end{array}$} & \multirow{7}{*}{$\begin{array}{c}8400<15900 \text { Look Back } \\
\text { Gagal }\end{array}$} \\
\hline & $\mathrm{n}=$ & 2 & & \\
\hline & Dn & 8400 & & \\
\hline & M & 2 & & \\
\hline & N'Dn & 8400 & & \\
\hline & $\mathrm{Dn}+1=$ & 8100 & & \\
\hline & $\mathrm{Dn}+2=$ & 7800 & & \\
\hline \multirow{5}{*}{$\begin{array}{c}\text { Look } \\
\text { Ahead } \\
\text { (Periode 3-4) }\end{array}$} & $\mathrm{N}^{\prime}=$ & 2 & \multirow{5}{*}{$13800>7800$} & \multirow{5}{*}{ Look Ahead Gagal } \\
\hline & $\mathrm{n}=$ & 2 & & \\
\hline & $\mathrm{Dn}+1=$ & 6900 & & \\
\hline & $\mathrm{Dn}+2=$ & 7800 & & \\
\hline & $\mathrm{N}^{\prime} \mathrm{Dn}+1=$ & 13800 & & \\
\hline \multirow{7}{*}{$\begin{array}{c}\text { Look Back } \\
\text { (Periode 3-4) }\end{array}$} & $\mathrm{N}^{\prime}=$ & 1 & & \multirow{7}{*}{$\begin{array}{c}7800<14700 \text { Look Back } \\
\text { Gagal }\end{array}$} \\
\hline & $\mathrm{n}=$ & 2 & \multirow{6}{*}{14700} & \\
\hline & Dn & 7800 & & \\
\hline & M & 2 & & \\
\hline & N'Dn & 7800 & & \\
\hline & $\mathrm{Dn}+1=$ & 6900 & & \\
\hline & $\mathrm{Dn}+2=$ & 7800 & & \\
\hline
\end{tabular}


Tabel 22. Tabel kebijakan metode PPB(ratusan)

\begin{tabular}{|c|c|c|c|c|c|c|}
\hline \multicolumn{7}{|c|}{ PPB } \\
\hline 0 & 1 & 2 & 3 & 4 & 5 & 6 \\
\hline D & 69 & 84 & 81 & 78 & 69 & 78 \\
\hline Lot & 153 & & 159 & & 147 & \\
\hline Por 153 & & 159 & & 147 & & \\
\hline
\end{tabular}

Tabel 23. Ongkos total metode PPB

\begin{tabular}{cc}
\hline \multicolumn{2}{c}{ PPB } \\
\hline Ongkos Pesan & Rp1.417.500 \\
Ongkos Simpan & Rp477.124 \\
Ongkos Total & Rp1.894.624 \\
\hline
\end{tabular}

Tabel 24. Ongkos wagner within

\begin{tabular}{lcccccc}
\hline \multicolumn{7}{c}{ Tabel Ongkos $(\mathrm{Rp})$} \\
\hline $\mathrm{T}$ & 1 & 2 & 3 & 4 & 5 & 6 \\
\hline 1 & $472.500,00$ & $639.492,00$ & $961.548,00$ & $1.426 .740,00$ & 1.975 .428 & 2.750 .748 \\
2 & & $472.500,00$ & $633.528,00$ & $943.656,00$ & 1.355 .172 & 1.975 .428 \\
3 & & $472.500,00$ & $627.564,00$ & 901.908 & 1.367 .100 \\
4 & & & $472.500,00$ & 609.672 & 919.800 \\
5 & & & & 472.500 & 627.564 \\
6 & & & & & 472.500 \\
\hline
\end{tabular}

Tabel 25. Perhitungan Fn

\begin{tabular}{ccccccc}
\hline \multicolumn{7}{c}{ Tabel Fn (Rp) } \\
\hline $\mathrm{T}$ & 1 & 2 & 3 & 4 & 5 & 6 \\
\hline 1 & $472.500,00$ & $639.492,00$ & $961.548,00$ & $1.426 .740,00$ & $1.975 .428,00$ & $2.750 .748,00$ \\
2 & & $945.000,00$ & $1.106 .028,00$ & $1.416 .156,00$ & $1.827 .672,00$ & $2.447 .928,00$ \\
3 & & & $1.417 .500,00$ & $1.572 .564,00$ & $1.846 .908,00$ & $2.312 .100,00$ \\
4 & & & & $1.890 .000,00$ & $2.027 .172,00$ & $2.337 .300,00$ \\
5 & & & & & $2.362 .500,00$ & $2.517 .564,00$ \\
6 & & & & & & $2.835 .000,00$ \\
Min & $472.500,00$ & $639.492,00$ & $961.548,00$ & $1.416 .156,00$ & $1.827 .672,00$ & $2.312 .100,00$ \\
\hline
\end{tabular}

Kemudian dapat diambil kesimpulan untuk metode PPB dalam tabel ongkos total inventory. Hasil ongkos total Inventory dengan menggunakan metode PPB dapat dilihat pada Tabel 23.

Pada Tabel 23 ongkos pesan yang dikeluarkan oleh UD. Roti lebih tinggi dibandingkan ongkos simpan. Sehingga untuk melakukan pemesanan pada UD. Roti tidak memerlukan pemesanan setiap minggu dan hanya melakukan pemesanan 3 kali. Sehingga perusahaan tidak memerlukan gudang yang luas sebagai tempat penyimpanan barang tersebut karena produk dipesan dan segera diproduksi.
Kelebihan dari pendekatan PPB ini adalah solusi ukuran lot ekonomis yang dihasilkan memiliki peluang lebih optimal dari solusi pendekatan dengan EPP, karena dasar dari pendekatan PPB adalah melakukan uji optimalitas terhadap hasil pendekatan dengan EPP.

Kekurangan metode ini adalah perhitungan yang tergolong rumit, dan juga terkadang jika "Look Ahead" dan "Look Back" gagal maka kita akan kembali menggunakan kebijakan dari metode economic part period yang dimana akan cenderung tidak efisien. Jika metode ini diterapkan pada perusahaan maka tidak diperlukan melakukan pemesanan barang pada setiap periodenya. 


\subsection{Metode Wagneer-Within}

Pendekatan ini merupakan pengembangan algoritma untuk menyelesaikan permasalahn inventori deterministik dinamis dengan menggunakan sistem matriks. Terdapat tiga tahapan perhitungan yang digunakan dalam mencari solusi optimal dengan pedekatan Wagner Within.

Langkah pertama (Bahagia, 2006):

Menghitung nilai Ogkos total inventori dari periode e sampai n (1-6). Dari O1.1 sampai O6.6. Dengan cara ongkos pesan ditambah ongkos simpan lalu dikali dengan Oen. Hasilnya bisa dilihat pada Tabel 24.

\section{Langkah kedua:}

Menghitung Fn dimana rumus Fn tersebut adalah min [Oen + Fe-1). Selanjutnya dari perhitungan Fn akan dibuat Tabel 25 rekap keseluruhan hasil perhitungan fn dari semua periode perhitungan, lalu perhitungan dapat dilihat yang mana nilai fn yang paling kecil. Hasil perhitungan lebih jelasnya dapat dilihat pada Tabel 25.

\section{Langkah Ketiga:}

Setelah langkah perhitungan Fn selesai dilakukan, selanjutnya adalah membuat kebijakan untuk mengetahui berapa kali jumlah pemesanan pada metode Wagner-Within ini. Hasil perhitungan tabel kebijakan inventori dapat dilihat pada Tabel 26.

Tabel 26. Kebijakan inventory wagner within(ratusan)

\begin{tabular}{lccccccc}
\hline \multicolumn{7}{c}{ WAGNEER-WITHIN } \\
\hline $\mathrm{T}$ & 0 & 1 & 2 & 3 & 4 & 5 & 6 \\
$\mathrm{D}$ & & 69 & 84 & 81 & 78 & 69 & 78 \\
Lot & & 153 & & 306 & & & \\
Por & 153 & & 306 & & & & \\
\hline
\end{tabular}

Sehingga diperoleh ongkos total inventory yang dikeluarkan pada UD.Roti (Tabel 27).

Tabel 27. Ongkos total wagner within

\begin{tabular}{ll}
\hline \multicolumn{2}{c}{ Wagner-Within } \\
\hline Ongkos Pesan & Rp945.000,00 \\
Ongkos Simpan & Rp1.061.592,00 \\
Ongkos Total & Rp2.006.592,00 \\
\hline
\end{tabular}

Pada metode Wagner - within diperoleh hasil bahwa pemesanan hanya dilakukan 2 kali dengan ongkos total sebesar Rp. 2.006.592,00. Dengan demikian UD. Roti lebih untung karena untuk pemesanan dalam 6 minggu hanya membutuhkan ongkos pesan sebesar Rp. 945.000.

Sedangkan jika UD. Roti memesan seperti biasanya yaitu 6 kali pemesanan, biaya yang dikeluarkan untuk memesan sebesar Rp. $2 . .835 .000$ selisihnya biaya sebesar Rp. 1.890 .000 tetapi dampak negatifnya pada metode wagner within ini banyak produk yang harus disimpan di gudang dalam waktu yang lama sehingga terjadi penumpukan dan ongkos simpannya yang lebih besar yaitu sebesar Rp. 1.061.592 dibandingkan dengan ongkos pesannya.

Kekurangan pada metode ini yaitu periode simpan bahan baku lebih lama sedangkan bahan baku UD. Roti berbentuk makanan yang memiliki waktu kadaluwarsa sehingga tidak baik jika disimpan terlalu lama.

Dari ke 8 metode deterministik dinamis dapat diambil kesimpulan mana metode terbaik dengan kriteria metode yang menghasilkan nilai ongkos total inventori paling kecil. Dan perbandingan antara ke 8 metode dapat dilihat pada Tabel 28 ongkos total inventory sebagai berikut:

Tabel 28. Perbandingan metode

\begin{tabular}{|c|c|}
\hline METODE & ONGKOS TOTAL \\
\hline LFL & Rp2.835.000,00 \\
\hline LUC & Rp1.894.624,18 \\
\hline LTC & Rp1.894.624,18 \\
\hline POQ & Rp2.750.767,97 \\
\hline EPP & Rp1.235.546,41 \\
\hline PPB & Rp1.894.624,18 \\
\hline WAGNER-WITHIN & Rp2.006.592,00 \\
\hline SILVER-MEAL & Rp2.043.725,49 \\
\hline
\end{tabular}

Pada Tabel 28 terlihat bahwa metode terbaik yang menghasilkan ongkos total inventori paling kecil yaitu metode EPP dengan total ongkos inventory sebesar Rp. 1.235.546,41 lebih kecil dibandingkan dengan metode yang lain sehingga metode EPP menjadi pilihan metode terbaik dengan kebijakan inventori yang paling optimal.

\section{KESIMPULAN}

Dari hasil pembahasan yang sudah dilakukan maka dapat disimpulkan bahwa Pengendalian persediaan yang optimal berdasarkan perhitungan deterministik dinamis adalah dengan menggunakan metode EPP. Dimana terdapat tiga kali pemesanan dengan 
ukuran lot pemesanan ekonomisnya adalah memesan sebesar 15300 unit pada periode 0 , 22800 unit dipesan pada periode 2 dan memsan 7800 unit pada periode 5. Ongkos total inventori dengan metode EPP mengahasilkan $\mathrm{Rp} \quad 1.235 .546$ dengan ongkos pesan Rp.945,000.00 dan ongkos simpan Rp.290,546.41

UD. Roti belum memiliki prosedur stock taking/stock opname dikarenakan tidak ada barang jadi yang sifatnya sebagai inventory, pada UD.Roti produk yang telah selesai dibuat langsung dikirim kepada customer dan karena memproduksi makanan khawatir kadarluarsa mengakibatkan tidak adanya barang yang disimpan di dalam gudang.

Diharapkan pada penelitian selanjutnya, optimasi biaya inventori bisa dikembangkan lagi melalui pengujian dengan pendekatan fenomena probabilistik dengan sifat permintaan yang tidak pasti dan leadtime (waktu ancangancang) yang berubah-rubah sesuai dengan kondisi dan ketersediaan material dari supplier.

\section{UCAPAN TERIMA KASIH}

Dengan dibuatnya jurnal mengenai Penentuan Persediaan Optimum pada UD. Roti Isabella, kami selaku pembuat jurnal ini, banyak mengucapkan terimakasih kepada Bapak Dude selaku pemilik UD. Roti atas kerjasama serta masukan dan saran yang diberikan kepada kami selama proses pengumpulan dan pengolahan data, sehingga kegiatan observasi yang dilakukan UD Roti berjalan dengan lancar dan optimal

\section{DAFTAR PUSTAKA}

Apple, J. M. (1990). Tata Letak Pabrik dan Pemindahan bahan (3rd ed.). Bandung: ITB.

Bahagia, S. N. (2006). Sistem Inventori. Bandung: Institut Teknologi Bandung.

Fatma, E., \& Pulungan, D. S. (2018). Analisis Pengendalian Persediaan Menggunakan Metode Probabilistik dengan Kebijakan Backorder dan Lost sales. Jurnal Teknik Industri.

https://doi.org/10.22219/jtiumm.vol19.no $1.38-48$

Hadiyanti, L., \& Siregar, M. T. (2018). Penentuan Frekuensi Pemesanan Komponen Lensa Kamera Menggunakan Metode Deterministik Dinamis untuk Meminimalisasi Biaya Persediaan pada
PT XACTI Indonesia. Jurnal Manajemen Industri Dan Logistik, 2(2), 192-205. https://doi.org/10.30988/jmil.v2i2.44

Handoko, T. H. (1995). Manajemen. Yogyakarta: BPFE.

Heizer dan Render. (2011). Prinsip-prinsip Manajemen Operasi. Jakarta: Salemba Empat.

Lahu, E. P., \& Sumarauw, J. S. B. (2017). Analisis Pengendalian Persediaan Bahan Baku Guna Meminimalkan Biaya Persediaan Pada Dunkin Donuts Manado. Jurnal EMBA: Jurnal Riset Ekonomi, Manajemen, Bisnis Dan Akuntansi, 5(3).

Limbong, I., Tarore, H., Tjakra, J., \& Walangitan, D. R. O. (2013). Manajemen Pengadaan Material Bangunan dengan Menggunakan Metode MRP (Material Requirement Planning) Studi Kasus: Revitalisasi Gedung Kantor BPS Propinsi Sulawesi Utara. Jurnal Sipil Statik.

Nangin, A. S., Nangoi, G. B., \& Tirayoh, V. Z. (2018). Penerapan Sistem Job Order Costing dalam Penentuan Harga Jual Produk Pada CV. Satu Satu Media Utama. GOING CONCERN: JURNAL RISET AKUNTANSI, 13(04). https://doi.org/10.32400/gc.13.04.20902. 2018

Tamodia, W. (2013). Evaluasi Penerapan Sistem Pengendalian Intern Untuk Persediaan Barang Dagangan Pada Pt. Laris Manis Utama Cabang Manado. Jurnal Riset Ekonomi, Manajemen, Bisnis Dan Akuntansi.

Tuerah, M. (2014). Analisis Pengendalian Persediaan Bahan Baku Ikan Tuna pada CV. Golden Kk. Jurnal Riset Ekonomi, Manajemen, Bisnis Dan Akuntansi. 